\title{
BMP5 wt Allele
}

National Cancer Institute

\section{Source}

National Cancer Institute. BMP5 wt Allele. NCI Thesaurus. Code C51531.

Human BMP5 wild-type allele is located in the vicinity of 6p12.1 and is approximately 120

$\mathrm{kb}$ in length. This allele, which encodes bone morphogenetic protein 5, plays a role in serine/threonine kinase signal transduction and induces cartilage and bone formation. 